\title{
Stimulation of Endothelial Cell Prostacyclin
}

\section{Production by}

\section{Thrombin, Trypsin, and the Ionophore A 23187}

\author{
Babette B. Weksler, Christopher W. Ley, and Eric A. Jaffe, Division of \\ Hematology-Oncology, Department of Medicine, Cornell University \\ Medical College, New York 10021
}

A в S T is A C T Prostacyclin $\left(\mathrm{PGI}_{2}\right)$ is an unstable prostaglandin which inhibits platelet aggregation and serotonin release and causes vasodilation. The $\mathrm{PGI}_{2}$ activity produced by monolayers of cultured human endothelial cells and fibroblasts was measured by the ability of their supernates to inhibit platelet aggregation in platelet-rich plasma, or to inhibit thrombininduced $\left[{ }^{14} \mathrm{C}\right]$ serotonin release from aspirin-treated, washed platelet suspensions. Monolayers of cultured human endothelial cells, stimulated with sodium arachidonate, thrombin, the ionophore A 23187, or trypsin, secreted $\mathrm{PGI}_{2}$ into the supernatant medium. Monolayers of fibroblasts produced $\mathrm{PGI}_{2}$ activity only when stimulated by arachidonate. "Resting," intact monolayers did not produce detectable $\mathrm{PGI}_{2}$, nor did monolayers treated with ADP or epinephrine. Production of $\mathrm{PGI}_{2}$ activity was abolished by treatment of the monolayers with indomethacin, tranylcypromine, or 15-hydroperoxy arachidonic acid. The $\mathrm{PGI}_{2}$ activity of the supernates was destroyed by boiling or acidification. Inhibition of thrombin with diisopropylfluorophosphate, and of trypsin with soybean trypsin inhibitor, abolished the stimulation of $\mathrm{PGI}_{2}$ production by these enzymes. Production of thrombin at a site of vascular injury could, by stimulating $\mathrm{PGI}_{2}$ synthesis by endothelial cells adjacent to the injured area, limit the number of platelets involved in the primary hemostatic response and help to localize thrombus formation.

\section{INTRODUCTION}

Prostacyclin $\left(\mathrm{PGI}_{2}\right)^{1}$ is a labile prostaglandin which inhibits platelet aggregation and serotonin release (1-3)

Eric A. Jaffe is the recipient of National Institutes of Health Research Career Development award 1 KO4 HL 00237 and a Career Scientist award from the Irma T. Hirschl Trust.

Received for publication 10 March 1978 and in revised form 30 May 1978.

${ }^{1}$ Abbreviations used in this paper: DFP, diisopropylfluorophosphate; HPAA, 15-hydroperoxy arachidonic acid; $\mathrm{PGI}_{2}$, prostacyclin; PRP, platelet-rich plasma. and counteracts the vasoconstrictive effects of plateletderived thromboxane $A_{2}$ by directly inducing vasodilation $(4,5)$. In tissues and in platelets, $\mathrm{PGI}_{2}$ produces a rise in intracellular cyclic AMP levels by stimulating adenylate cyclase (6-9). We have previously demonstrated that suspensions of cultured human and bovine endothelial cells produce $\mathrm{PGI}_{2}$ when stimulated with sodium arachidonate or when incubated with platelets capable of generating prostaglandin endoperoxides (10).

We now report that intact monolayers of human cultured endothelial cells incubated with thrombin, the ionophore A 23187, trypsin, or sodium arachidonate produce $\mathrm{PGI}_{2}$. However, "resting", undisturbed endothelial cell monolayers as well as monolayers treated with ADP or epinephrine do not produce significant amounts of $\mathrm{PGI}_{2}$.

\section{METHODS}

Endothelial cell and fibroblast monolayer cultures. Human endothelial cells derived from umbilical cord veins were cultured in T-25 flasks in Medium 199 which contained 20\% pooled human serum, with techniques previously described (11). Flasks which contained confluent endothelial cell cultures in passages $1-5$ were used in these studies; 38 separate lines were evaluated. 10 lines of fibroblasts derived from human embryo skin, human adult skin, and human foreskin were obtained from Doctors Gretchen Darlington and Ted Brown (Cornell University Medical College), the American Type Culture Collection, Rockville, Md. (Registry nos. CCL 110 and CCL 75 (WI-38)), and the Institute for Medical Research, Camden, N. J. (Registry nos. IMR-90, IMR-91, GM-1603, GM1604, AG-2257, and AG-2258). The fibroblasts were cultured in minimal essential medium (Flow Laboratories, Inc., Rockville, Md.) which contained 10 or $15 \%$ fetal calf serum (depending upon the fibroblast line used), and were used in passages 3-37 when confluent. Before use, the culture medium was removed and the cell monolayers were washed twice with gentle rinsing with $5 \mathrm{ml}$ Buffer A $(10 \mathrm{mM}$ Hepes, $\mathrm{pH}$ $7.55,150 \mathrm{mM} \mathrm{NaCl}, 5 \mathrm{mM} \mathrm{KCl}, 1.8 \mathrm{mM} \mathrm{CaCl}_{2}, 1 \mathrm{mM} \mathrm{MgCl}$, and $5 \mathrm{mM}$ glucose). Stimuli were added to Buffer $\mathrm{A}$ at desired concentrations and then $2.5 \mathrm{ml}$ of the mixture was incubated with the washed monolayers for $30 \mathrm{~s}-10 \mathrm{~min}$. Stimuli used included arachidonic acid, 3'5'-ADP (both from Sigma Chemical Co., St. Louis, Mo.), ionophore A 23187 (a gift from 
Dr. R. L. Hamill, Eli Lilly and Company, Indianapolis, Ind.), epinephrine (Parke, Davis \& Company, Detroit, Mich.), 9,11azoprostanoid III (a gift from Dr. E. J. Corey, Harvard University, Cambridge, Mass.), and purified human thrombin (a gift from J. Fenton, Albany, N. Y.). The supernatant fluid was then removed and tested immediately for $\mathbf{P G I}_{2}$ by bioassay (vide infra) or kept on ice until use. Authentic PGI $_{2}$ (a gift from Dr. K. C. Nicolaou, University of Pennsylvania, Philadelphia, $\mathrm{Pa}$.) was used as a standard. After the incubation, the endothelial cells (or fibroblasts) were removed from the culture flasks by treatment with collagenase $(0.1 \%, 10 \mathrm{~min}$, $37^{\circ} \mathrm{C}$ ) and counted in a hemocytometer. Cell counts in all flasks of any one cell type used on any given day varied by $<10 \%$. Flasks of endothelial cells contained $0.6-1.7 \times 10^{6}$ cells/flask, and flasks of fibroblasts contained $0.8-1.7 \times 10^{6}$ cells/flask.

Platelet preparations. Blood from normal human donors who had not ingested aspirin-containing drugs for at least 10 days was obtained by venipuncture, with a two-syringe technique, and mixed with 0.1 vol of $3.2 \%$ trisodium citrate. Platelet-rich plasma (PRP) was prepared by centrifugation at $150 \mathrm{~g}$ for $10 \mathrm{~min}$ at room temperature and was kept tightly capped under $5 \% \mathrm{CO}_{2}: 95 \%$ air until use.

Washed platelet suspensions for the thrombin release assay (vide infra) were prepared from normal human venous blood drawn into $1 / 6$ vol of acid citrate dextrose following a modification of the procedure of Mustard et al. (12) as previously described (10). In addition, the platelets were incubated with $100 \mu \mathrm{M}$ aspirin for $20 \mathrm{~min}$ in the first washing buffer to prevent generation of endogenous prostaglandin endoperoxide or thromboxane $\mathrm{A}_{2}$. The platelet suspension was labeled with $\left[2{ }^{\prime}-{ }^{14} \mathrm{C}\right] 5$-hydroxytryptamine creatinine sulfate (sp act $53 \mathrm{mCi} /$ mmol, Amersham Corp., Arlington Heights, Ill.) in the second washing buffer by addition of $0.167-0.555 \mu \mathrm{Ci} / \mathrm{ml}$ platelet suspension (to give a serotonin concentration of 3-10.5 $\mu \mathrm{M}$ ) for $15 \mathrm{~min}$ at $37^{\circ} \mathrm{C}$. Approximately $90-95 \%$ of the $\left[{ }^{14} \mathrm{C}\right]$ serotonin was taken up by the platelets. The washing procedure was then completed and the platelet suspension was adjusted to 500,000 platelets $/ \mu \mathrm{l}$ in Tyrode's solution which contained $0.1 \%$ apyrase and $0.35 \%$ bovine serum albumin.

Platelet aggregation. Platelet aggregation studies were performed with $0.4 \mathrm{ml}$ aliquots of PRP stirred at $1,000 \mathrm{rpm}$ at $37^{\circ} \mathrm{C}$ in a dual channel Payton aggregation module with a linear recorder (Payton Associates, Buffalo, N. Y.). Final reaction volumes were $0.5 \mathrm{ml}$. Threshold values of arachidonic acid (usually $0.2-0.5 \mathrm{mM}$ ) were determined for each batch of PRP and were used throughout the experiment to induce aggregation. 90-98 $\mu \mathrm{l}$ of Buffer A or endothelial cell (or fibroblast) supernate was added to the cuvette which contained PRP at $37^{\circ} \mathrm{C}$ and stirred for $1 \mathrm{~min}$. Then the threshold-dose of aggregating agent was added and the response recorded.

Thrombin release assay. The release of $\left[{ }^{14} \mathrm{C}\right]$ serotonin from prelabeled, washed, aspirin-treated platelet suspensions by thrombin in the presence or absence of $\mathrm{PGI}_{2}$ or supernatant fluids which contained $\mathrm{PGI}_{2}$ was measured by modifications of the method of Baenziger et al. (13). The final suspension of platelets contained $1 \mu \mathrm{M}$ imipramine to prevent re-uptake of released serotonin during the assay. Endothelial cell or fibroblast supernates were removed from the culture flasks, $320 \mu \mathrm{l}$ of supernate was mixed with $1.6 \mathrm{ml}$ of platelet suspension for $2 \mathrm{~min}$ and $240-\mu \mathrm{l}$ portions of the treated platelet suspension were then placed into a series of $1.5 \mathrm{ml}$ polypropylene centrifuge tubes in a $37^{\circ} \mathrm{C}$ dry heating block. At 10-s intervals, $10 \mu \mathrm{l}$ of different dilutions of thrombin were added to give final thrombin concentrations of $0,0.05$, $0.1,0.25,0.5,1.0,5.0$, and $10.0 \mathrm{U} / \mathrm{ml}$. After the platelet suspensions were incubated at $37^{\circ} \mathrm{C}$ with thrombin for exactly $2 \mathrm{~min}$, the reaction was stopped by addition of $0.25 \mathrm{ml}$ of ice-cold $2.4 \%$ paraformaldehyde, and the tubes were transferred to an ice bath. The chilled tubes were then centifuged for $30 \mathrm{~s}$ at $8,000 \mathrm{~g}$ and $200-\mu \mathrm{l}$ samples of each supernate were placed in scintillation minivials which contained $2.7 \mathrm{ml}$ of PCS (Amersham Corp.) and $0.1 \mathrm{ml}$ of $\mathrm{H}_{2} \mathrm{O}$, and were counted in a Searle Mark III liquid scintillation counter (Searle Diagnostics Inc., subsid. of G. D. Searle \& Co., Des Plaines, Ill.). In some experiments, the platelet suspension was directly layered over the cell monolayers in tissue culture flasks for $2 \mathrm{~min}$ and then removed and tested as above.

A release curve was constructed by plotting the percent of serotonin released into the supernate of the platelet suspension against the log of the thrombin concentration. The data were analyzed by linearizing the standard dose:response curve with the logit transformation (14). A linear least-squares regression analysis of logit $\left(B / B_{0}\right)$ versus $\ln$ thrombin concentration (in $\mathrm{U} / \mathrm{ml}$ ) was performed on an $\mathrm{HP}-97$ programmable desk calculator (Hewlett-Packard Corp., McMinnville Div., McMinnville, Oreg.). The correlation coefficient $(r)$ in all cases was $>0.95$, and was usually $>0.99$. In this analysis, $B$ is the serotonin (as disintegrations per minute) retained in the platelets (i.e., the total serotonin minus the serotonin released) at an experimental point, $B_{0}$ is the disintegrations per minute retained at zero thrombin concentration, and $\mathrm{N}$ is the disintegrations per minute retained at the concentration of thrombin giving maximal release. Logit $\left(B / B_{0}\right)$ is $\ln (B-N) /$ $\left(B_{0}-B\right)$. The thrombin concentration which yielded $50 \%$ of maximum release was calculated $\left(T_{50}\right)$. Thus the effects of $\mathrm{PGI}_{2}$ in monolayer supernates on thrombin-induced serotonin release can be expressed quantitatively as the percent change in the thrombin concentration producing $50 \%$ of maximal release $\left(\Delta \mathrm{T}_{50}\right)$ where,

$$
\Delta \mathrm{T}_{50}=\frac{\mathrm{T}_{50}(\text { sample })-\mathrm{T}_{50}(\text { control })}{\mathrm{T}_{50}(\text { control })} \times 100 .
$$

Expressing resuts in terms of $\Delta \mathrm{T}_{50}$ allowed us to compensate for the variation in thrombin sensitivity observed among platelet donors. The results of experiments performed on the same day on replicates from the same cell line usually varied by $<12 \%$. The results of this assay were assessed statistically with a one sample $t$ test where the null hypothesis was a $\Delta \mathrm{T}_{50}=0$ (i.e., no effect).

Evaluation for carryover of agents used to stimulate monolayers. The possibility that agents used to stimulate endothelial cell or fibroblast monolayers might be carried over in the monolayer supernate and alter the thrombin-induced serotonin release assay results was evaluated. Thrombin carryover will affect the $\left[{ }^{14} \mathrm{C}\right]$ serotonin release assay either by decreasing the $\mathrm{T}_{50}$ or by causing the release of $\left[{ }^{14} \mathrm{C}\right]$ serotonin from platelets in control tubes from which thrombin has been omitted. To assay for residual thrombin, $\mathbf{P G I}_{2}$ was eliminated either by running an empty-dish control or by treating the cell monolayers with indomethacin to block $\mathrm{PGI}_{2}$ production. We therefore incubated thrombin $(0.1 \mathrm{U} / \mathrm{ml})$ in buffer either in an empty dish or with indomethacin-treated endothelial and fibroblast monolayers for $2 \mathrm{~min}$ at $37^{\circ} \mathrm{C}$ and then assayed the thrombin containing buffer in our usual assay procedure. In both models, thrombin at an initial concentration of $0.1 \mathrm{U} / \mathrm{ml}$ (which would yield thrombin at $0.02 \mathrm{U} / \mathrm{ml}$ after 1:5 dilution in the assay) neither lowered the $\mathrm{T}_{50}$ nor released $\left[{ }^{14} \mathrm{C}\right]$ serotonin from platelets in control tubes from which thrombin was omitted. However, thrombin at an initial concentration of $0.5 \mathrm{U} / \mathrm{ml}$ in both models produced a decrease of $T_{50}$ and caused release of $\left[{ }^{14} \mathrm{C}\right]$ serotonin from platelets in control tubes from which thrombin was omitted. The release of $\left[{ }^{14} \mathrm{C}\right]$ serotonin seen in this case was directly equivalent to that obtained with thrombin $(0.1 \mathrm{U} / \mathrm{ml}$ ) in our assay (because the supernate is diluted 1:5 
in the assay). Despite this finding, when nonindomethacintreated endothelial cells were incubated with thrombin at 0.5 $\mathrm{U} / \mathrm{ml}$, the endothelial cell supernate reproducibly increased the $\mathrm{T}_{50}$ and did not release $\left[{ }^{14} \mathrm{C}\right]$ serotonin from platelets in control tubes which lacked thrombin. On the other hand, supernates from nonindomethacin-treated fibroblasts incubated with thrombin at $0.5 \mathrm{U} / \mathrm{ml}$ consistently decreased the $\mathrm{T}_{50}$ and produced $\left[{ }^{14} \mathrm{C}\right]$ serotonin release in platelets in control tubes which lacked thrombin equivalent to that produced by thrombin at $0.1 \mathrm{U} / \mathrm{ml}$. Thus, in the case of endothelial cells stimulated with thrombin at $0.5 \mathrm{U} / \mathrm{ml}$, a net effect is seen whereby the amount of $\mathrm{PGI}_{2}$ produced reverses not only the effect of the residual thrombin, but also some of the thrombin added in the assay, thus significantly increasing the $T_{50}$. It is therefore likely that the increased $\mathrm{T}_{50}$, observed when endothelial cells are stimulated with thrombin at $0.5 \mathrm{U} / \mathrm{ml}$, underestimates the true amount of $\mathrm{PGI}_{2}$ produced.

Carryover of sodium arachidonate, ADP, trypsin, and the ionophore A 23187 at the doses used did not affect the assay because the platelets had been treated with aspirin and thus were unresponsive to these agents. Epinephrine produced a decrease in the $T_{50}$ at all doses used. Possible production of "hidden" $\mathrm{PGI}_{2}$ by endothelial cells and fibroblasts stimulated by epinephrine was ruled out by showing that the decrease in $T_{50}$ was the same whether or not the cells had been treated with indomethacin.

Similar experiments were performed to rule out the effects of carryover of agents in monolayer supernates used in platelet aggregation studies.

Inhibition of $\mathrm{PGI}_{2}$ production. Endothelial cell and fibroblast monolayers were washed free of medium and incubated for $20 \mathrm{~min}$ at $37^{\circ} \mathrm{C}$ with the cyclo-oxygenase inhibitor indomethacin $(10 \mu \mathrm{g} / \mathrm{ml})$ (Sigma Chemical Co.), or with the inhibitors of prostacyclin synthesis $(15,16)$, 15-hydroperoxyarachidonic acid (HPAA) $(30 \mu \mathrm{g} / \mathrm{ml})$ (generously provided by Dr. A. Marcus, Cornell University Medical College) or tranylcypromine $(500 \mu \mathrm{g} / \mathrm{ml}$ ) (a gift from Dr. H. Green, Smith, Kline \& French, Philadelphia, Pa.). Incubations with inhibitors were carried out in Buffer A. Indomethacin and 15-HPAA were removed before the monolayers were stimulated. Tranylcypromine inhibition was assayed both in the presence of drug and after its removal. While indomethacin is a reversible inhibitor of cyclo-oxygenase (17), its effect was not reversed during the short course of our experiment, which included the removal of the indomethacin, a washing of the monolayer with buffer, and a stimulation of the cell monolayers for 2 min with a variety of agents which included arachidonate $(20 \mu \mathrm{M})$.

Thrombin was inactivated by incubation with diisopropylfluorophosphate (DFP), $10 \mathrm{mM}$, for $30 \mathrm{~min}$ at room temperature, followed by dialysis overnight against $0.75 \mathrm{M} \mathrm{NaCl}-0.1$ $\mathrm{M}$ Tris, $\mathrm{pH} 8.3$, at $4^{\circ} \mathrm{C}$ to remove the excess DFP. DFP treatment decreased thrombin ability to aggregate platelets by more than $90 \%$. Native thrombin used as a control was similarly dialyzed and retained full platelet aggregating activity.

Inhibition of $P G I_{2}$ activity. $\mathrm{PGI}_{2}$ or monolayer supernates which contained $\mathrm{PGI}_{2}$ activity were inactivated by boiling for $30 \mathrm{~s}$ or by acidification to $\mathrm{pH} 3$ for $10 \mathrm{~min}$ followed by back titration to $\mathrm{pH} 7.5$.

\section{RESULTS}

Inhibition of platelet aggregation by supernates from cell monolayers. Endothelial cell monolayers were washed free of culture medium and incubated with Buffer $\mathrm{A}$. The release of $\mathrm{PGI}_{2}$ activity into the overlying buffer was measured by the buffer capacity to inhibit platelet aggregation when added to PRP (Fig. 1). This method detects $0.1 \mathrm{ng} / \mathrm{ml}$ of $\mathrm{PGI}_{2}$ (data not shown). No inhibition of platelet aggregation occurred in the presence of buffer or $10 \%$ ( $\mathrm{vol} / \mathrm{vol}$ ) monolayer supernate taken from resting endothelial cells (Fig. 1A, curves 1 and 2). However, the supernatant fluid from endothelial cell monolayers incubated for 2 min with $20 \mu \mathrm{M}$ sodium arachidonate markedly inhibited platelet aggregation (Fig. 1A, curve 3). Endothelial cell monolayers were compared to fibroblast monolayers for capacity to generate $\mathrm{PGI}_{2}$ activity in their supernate (Fig. 1B). Fibroblasts derived from embryonic skin, foreskin, or adult skin all yielded the same results and are thus considered together. Resting skin fibroblasts did not produce inhibitory supernates (Fig. 1B, curve 5). Skin fibroblast monolayers often, but not invariably, generated inhibitory activity in the presence of $20 \mu \mathrm{M}$ arachidonate (Fig. 1B, curve 6). As little as $2 \mu \mathrm{l}$ of supernate derived from incubation of $20 \mu \mathrm{M}$ sodium arachidonate with $4 \times 10^{5}$ endothelial cells/ml of Buffer A completely inhibited platelet aggregation in PRP. This was equivalent to inhibition by $0.1 \mathrm{nM} \mathrm{PGI}{ }_{2}$ or by $90-100 \mu \mathrm{l}$ of supernate from similarly incubated fibroblast monolayers.

Endothelial cell and fibroblast monolayers were incubated with a number of agents that aggregate platelets (with concentrations, however, which at the same dilution alone did not produce aggregation in test PRP). The supernatant medium was then removed and tested for its effects on platelet aggregation in PRP challenged
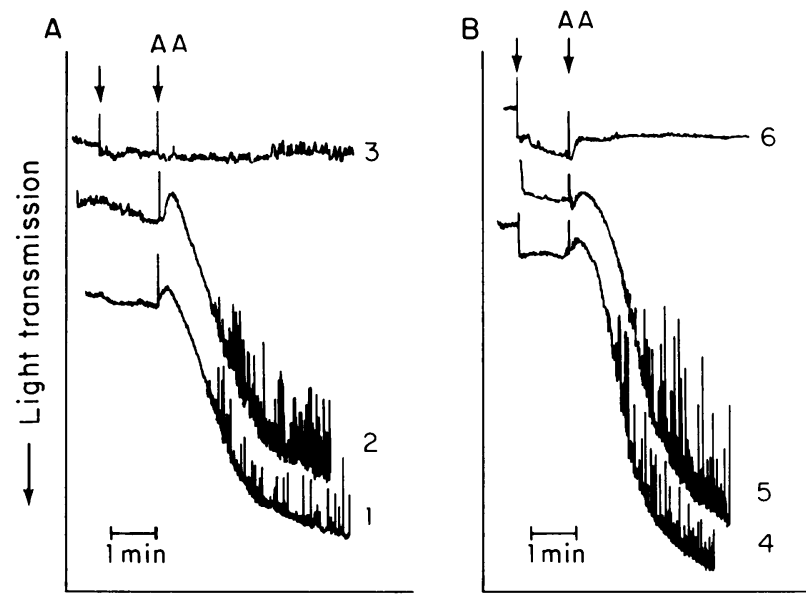

FIGURE 1 Inhibition of platelet aggregation in PRP by supernates from monolayers of endothelial cells (A) and fibroblasts (B). Supernates were added at the first arrow and $0.3 \mathrm{mM}$ sodium arachidonate (AA) at the second arrow. (A) (1) Control-Buffer A, (2) Supernate from unstimulated endothelial cells, and (3) supernate from endothelial cells stimulated with $20 \mu \mathrm{M}$ sodium arachidonate (AA). (B) (4) Control-Buffer A, (5) supernate from unstimulated skin fibroblasts, and (6) supernate from skin fibroblasts stimulated with $20 \mu \mathrm{M}$ sodium arachidonate (AA). 
with sodium arachidonate. Neither the culture medium nor the buffer used to wash the resting monolayers produced any change in the normal aggregation responses of PRP. Endothelial cell monolayers incubated with sodium arachidonate $(20 \mu \mathrm{M})$, thrombin $(0.1 \mathrm{U} / \mathrm{ml})$, or the ionophore A $23187(10 \mu \mathrm{M})$ released $\mathrm{PGI}_{2}$ activity into the supernatant buffer. These supernates inhibited platelet aggregation in PRP stimulated by arachidonate. ADP (1-5 $\mu \mathrm{M})$, epinephrine $(0.1-1 \mu \mathrm{M})$, and the endoperoxide analogue, azoprostanoid III $(12.6 \mu \mathrm{g} / \mathrm{ml})$, did not stimulate production of $\mathrm{PGI}_{2}$ by endothelial cell monolayers in this test system. Fibroblast monolayers derived from skin produced $\mathrm{PGI}_{2}$ activity only after incubation with arachidonate $(20 \mu \mathrm{M})$. Incubation with ionophore A 23187, thrombin, ADP, epinephrine, or azoprostanoid III at the same doses as used on endothelial cells did not stimulate production of $\mathrm{PGI}_{2}$ by fibroblast monolayers in this test system.

Mechanical stimulation of endothelial cell monolayers by a rubber policeman in the absence of any other stimulus led to the rapid appearance of $\mathrm{PGI}_{2}$ activity in the supernate.

Inhibition of $\left[{ }^{14} \mathrm{C}\right]$ serotonin release: quantitation of $P G I_{2}$ activity produced by endothelial cell and fibroblast monolayers. Inhibition of thrombin-induced release of $\left[{ }^{14} \mathrm{C}\right]$ serotonin from aspirin-treated, washed platelets by synthetic $\mathbf{P G I}_{2}$ or by supernatant fluids from endothelial cell and fibroblast monolayers was used to measure $\mathrm{PGI}_{2}$ activity. Treatment of a washed platelet suspension with $\mathrm{PGI}_{2}$ or with cell monolayer supernates which contained $\mathrm{PGI}_{2}$ activity made the platelets less sensitive to thrombin, and thus shifted the curve of serotonin release. Examples of a standard curve of serotonin release and the effect of $10 \mathrm{nM}$ of $\mathrm{PGI}_{2}$ on this curve are shown in Fig. 2A. By means of a logit transformation of the data (Fig. 2B) the release curves are linearized and the $\mathrm{T}_{50}$ (thrombin concentration which produces $50 \%$ of the maximal serotonin release) can be calculated. This assay can detect $\mathrm{PGI}_{2}$ at concentrations as low as $10-100 \mathrm{pM}$ depending upon the platelet donor. The concentration of thrombin required to liberate $50 \%$ of maximally releasable $\left[{ }^{14} \mathrm{C}\right]$ serotonin from control platelets was $0.25 \pm 0.14$ $\mathrm{U} / \mathrm{ml}$ (mean $\pm \mathrm{SD}, n=36$ ) in this system. While the inter-donor variation in platelet sensitivity to thrombin was quite large, the intra-donor variation was much smaller (i.e., average coefficient of variation $=15.3 \%$ ).

We used the quantitative $\left[{ }^{14} \mathrm{C}\right]$ serotonin-release assay to compare the production of $\mathrm{PGI}_{2}$ activity by endothelial cell monolayers stimulated by different agents. Because $\mathrm{PGI}_{2}$ activity shifted the $\left[{ }^{14} \mathrm{C}\right]$ serotonin release curve and increased the $T_{50}$, the $\mathrm{PGI}_{2}$ effect was expressed as percent change in $\mathrm{T}_{50}$ or $\Delta \mathrm{T}_{50}$ (Methods).

Endothelial cell monolayers, incubated with buffer alone, produced no detectable $\mathrm{PGI}_{2}$ activity when compared to control, untreated platelets (Table I). The ad-

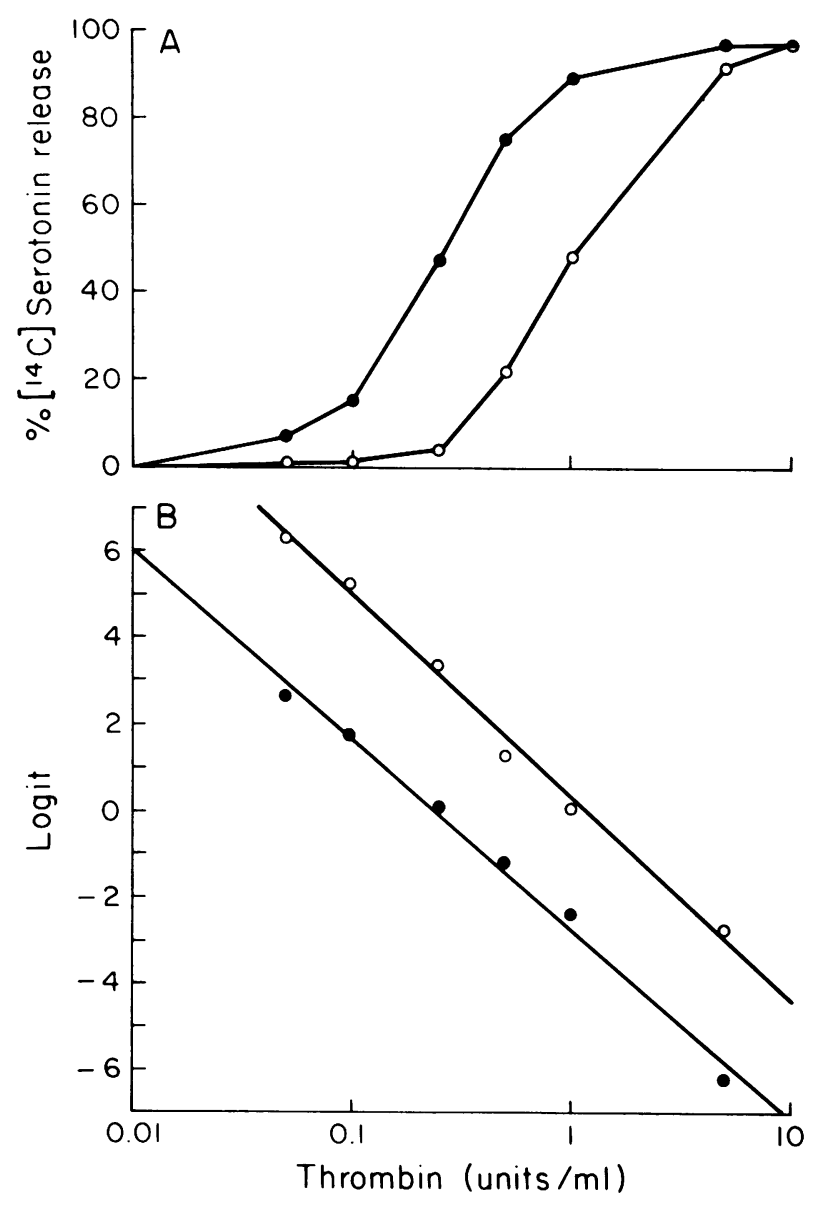

FIgURE 2 Inhibition of thrombin-induced $\left[{ }^{14} \mathrm{C}\right]$ serotonin release from aspirin-treated, washed platelets by $\mathrm{PGI}_{2}$. (A) $\left[{ }^{14} \mathrm{C}\right]$ Serotonin release as a function of thrombin concentration in the presence of Buffer $A(O)$ and in the presence of $10 \mathrm{nM} P \mathrm{PG}_{2}$ (O). (B) Logit plot of data in panel A. $50 \%$ release of $\left[{ }^{14} \mathrm{C}\right]$ serotonin $\left(\mathrm{T}_{50}\right)$ occurs at logit $=0$.

dition of exogenous arachidonate resulted in significant production of $\mathrm{PGI}_{2}$ activity. Thrombin treatment of endothelial cell monolayers also resulted in significant $\mathrm{PGI}_{2}$ production related to the dose of thrombin used. No thrombin carryover effect was noted with thrombin at $0.1 \mathrm{U} / \mathrm{ml}$. However, $0.5 \mathrm{U} / \mathrm{ml}$ doses of thrombin produced carryover (Methods). Despite the carryover of thrombin, the endothelial cells produced enough $\mathbf{P G I}_{2}$ to completely mask the presence of residual thrombin. It is therefore likely that the $T_{50}$ observed when endothelial cells are stimulated with $0.5 \mathrm{U} / \mathrm{ml}$ of thrombin underestimates the true amount of $\mathrm{PGI}_{2}$ produced. Treatment of endothelial cell monolayers with DFPinactivated thrombin did not stimulate $\mathrm{PGI}_{2}$ synthesis. The ionophore A 23187 stimulated production of large amounts of $\mathrm{PGI}_{2}$ activity in a dose-related fashion. ADP did not lead to significant $\mathrm{PGI}_{2}$ production. Epinephrine was ineffective in stimulating $\mathrm{PGI}_{2}$ production. More- 
TABLE I

$\mathrm{PGI}_{2}$ Production in Stimulated Endothelial Cell Monolayers

\begin{tabular}{lcccc}
\hline & $\Delta \mathrm{T}_{\mathbf{s 0}^{*}}$ & SEM & $n$ & $P$ \\
\hline $\begin{array}{l}\text { Control platelets } \\
\text { Endothelial cells } \S\end{array}$ & 0 & - & 36 & - \\
$\quad$ Buffer A & & & & \\
$\quad \begin{array}{l}\text { Sodium arachidonate } \\
\quad(20 \mu \mathrm{M})\end{array}$ & 271 & 43.4 & 18 & $<0.0001$ \\
$\quad$ Thrombin & & & & \\
$\quad(0.5 \mathrm{U} / \mathrm{ml})$ & 171 & 21.9 & 7 & $<0.0001$ \\
$\quad(0.1 \mathrm{U} / \mathrm{ml})$ & 73 & 21.3 & 5 & $<0.05$ \\
Ionophore A 23187 & & & & \\
$\quad(10 \mu \mathrm{M})$ & 512 & 177 & 6 & $<0.05$ \\
$\quad(5 \mu \mathrm{M})$ & 433 & 67.9 & 4 & $<0.01$ \\
ADP $(5 \mu \mathrm{M})$ & 10.7 & 6.6 & 6 & $\mathrm{NS}$ \\
Epinephrine $(0.9 \mu \mathrm{M})$ & -33.8 & 2.9 & 8 & $<0.0001$ \\
\hline
\end{tabular}

$* \Delta \mathrm{T}_{50}=\frac{\mathrm{T}_{50}-\mathrm{T}_{50} \text { (control) }}{\mathrm{T}_{50} \text { (control) }} \times 100 \%$.

$\$ \mathrm{~T}_{50}$ of control platelets $=0.25 \pm 0.14 \mathrm{U} / \mathrm{ml}($ mean $\pm \mathrm{SD}, n=36)$. $\S$ Endothelial cell monolayers were incubated with the listed agents for $2 \mathrm{~min}$ at $37^{\circ} \mathrm{C}$ and the supernates removed and tested. All agents were dissolved in Buffer A.

over, supernates from the epinephrine-treated endothelial cells potentiated thrombin-induced serotonin release and lowered the $T_{50}$ because of epinephrine carryover.

Fibroblasts, incubated under identical conditions, produced statistically significant amounts of $\mathbf{P G I}_{2}$ only when stimulated by arachidonate (Table II). Thrombin, ionophore A 23187, and ADP did not stimulate the production of statistically significant amounts of $\mathrm{PGI}_{2}$. Epinephrine, as in endothelial cells, significantly potentiated thrombin-induced serotonin release. Fibroblasts as early as passage 3 were unresponsive to thrombin and ionophore, whereas endothelial cells at all passages tested (passages $1-5$ ) produced $\mathrm{PGI}_{2}$ in response to these stimuli.

Time course of $\mathrm{PGI}_{2}$ production after stimulation of monolayers. The production of $\mathrm{PGI}_{2}$ activity after stimulation of endothelial cell monolayers by sodium arachidonate or thrombin was rapid and transient. Maximum production of $\mathrm{PGI}_{2}$ was observed within 1-2 min, as measured semiquantitatively by the delay in platelet aggregation induced by aliquots of supernate sequentially removed from monolayers stimulated with arachidonate $(20 \mu \mathrm{M})$ or thrombin $(0.5 \mathrm{U} / \mathrm{ml})$. $\mathrm{PGI}_{2}$ activity was undetectable $10 \mathrm{~min}$ after stimulation. Production of $\mathrm{PGI}_{2}$ activity by fibroblasts stimulated with sodium arachidonate followed a similar time course.

Once stimulated, an endothelial cell monolayer was less responsive to a second stimulation given $15 \mathrm{~min}$ to $1 \mathrm{~h}$ later. Thus the response to a second arachidonate stimulus was about $40 \%$ less than to the first arachi-
TABLE II

$\mathrm{PGI}_{2}$ Production in Stimulated Skin Fibroblast Monolayers

\begin{tabular}{lcccc}
\hline & $\Delta \mathrm{T}_{\mathbf{5 0}^{*}}{ }^{*}$ & SEM & $n$ & $P$ \\
\hline Control platelets $\downarrow$ & 0 & - & 17 & - \\
Fibroblasts $\S$ & & & & \\
$\quad$ Sodium arachidonate & & & & \\
$\quad(20 \mu \mathrm{M})$ & 148.4 & 51.4 & 9 & $<0.02$ \\
$\quad$ Thrombin $(0.1 \mathrm{U} / \mathrm{ml})$ & 21.8 & 13.9 & 5 & $\mathrm{NS}$ \\
Ionophore A $23187(10 \mu \mathrm{M})$ & 33.3 & 17.5 & 4 & $\mathrm{NS}$ \\
ADP $(5 \mu \mathrm{M})$ & 2.2 & 15.5 & 3 & $\mathrm{NS}$ \\
$\quad$ Epinephrine $(0.9 \mu \mathrm{M})$ & -33 & 7.5 & 3 & $<0.05$ \\
\end{tabular}

$* \Delta \mathrm{T}_{50}=\frac{\mathrm{T}_{50}-\mathrm{T}_{50}(\text { control })}{\mathrm{T}_{50}(\text { control })} \times 100$.

$\$ \mathrm{~T}_{\mathbf{5 0}}$ of control platelets $=0.25 \pm 0.09 \mathrm{U} / \mathrm{ml}($ mean $\pm \mathrm{SD}, n=17)$. $\S$ Fibroblast monolayers were incubated with the listed agents for $2 \mathrm{~min}$ at $37^{\circ} \mathrm{C}$ and the supernates removed and tested. All agents were dissolved in Buffer A.

donate stimulus. A monolayer stimulated first with thrombin produced $\mathrm{PGI}_{2}$ in response to a second stimulation by arachidonate; however, a monolayer stimulated first with arachidonate subsequently responded poorly to thrombin. In addition, a monolayer which produced $\mathrm{PGI}_{2}$ upon thrombin-stimulation failed to respond to a second exposure with thrombin.

Inhibition of $\mathrm{PGI}_{2}$ production in monolayers of endothelial cells. Indomethacin-treated monolayers of endothelial cells did not produce $\mathrm{PGI}_{2}$ activity when stimulated with sodium arachidonate (Table III). Production of $\mathrm{PGI}_{2}$ activity by endothelial cell monolayers stimulated with sodium arachidonate was also prevented by incubation of the monolayers with 15-HPAA $(30 \mu \mathrm{g} / \mathrm{ml})$ or with tranylcypromine $(0.5 \mathrm{mg} / \mathrm{ml})$, both inhibitors of $\mathrm{PGI}_{2}$ synthesis. Significant inhibition of

\section{TABLE III \\ Inhibition of $\mathrm{PGI}_{2}$ Production by Endothelial Cell Monolayers}

\begin{tabular}{lc}
\hline \multicolumn{1}{c}{ Inhibitor* } & Inhibitiont \\
\hline & $\%$ \\
None (Buffer control) & 0 \\
Indomethacin $(10 \mu \mathrm{g} / \mathrm{ml})$ & 94 \\
15-Hydroperoxy arachidonate $(30 \mu \mathrm{g} / \mathrm{ml})$ & 100 \\
Tranylcypromine & \\
$\quad$ Prior incubation only $(500 \mu \mathrm{g} / \mathrm{ml})$ & 29 \\
Coincubation $(500 \mu \mathrm{g} / \mathrm{ml})$ & 69 \\
\hline
\end{tabular}

* Endothelial cell monolayers $\left(10^{6}\right.$ cells $)$ were treated with the stated inhibitors and then incubated for 2 min with 2.5 $\mathrm{ml}$ of Buffer A which contained $20 \mu \mathrm{M}$ arachidonate. Supernates were then removed and tested in the $\left[{ }^{14} \mathrm{C}\right]$ serotonin release assay.

$\ddagger$ Inhibition is expressed as the percent decrease in $\Delta T_{50}$. 
$\mathrm{PGI}_{2}$ production by tranylcypromine, unlike 15-HPAA, required the latter's presence during incubation of endothelial cell monolayers with arachidonate, which indicates that the inhibitory effect of tranylcypromine was reversible. The production of $\mathrm{PGI}_{2}$ by endothelial cells stimulated by thrombin, trypsin, and ionophore A 23187 were also inhibited by treatment with indomethacin. Indomethacin-treated monolayers could produce $\mathrm{PGI}_{2}$ when incubated with normal PRP but not when incubated with aspirin-treated PRP. These results are consistent with the inhibition of endothelial cell cyclo-oxygenase by indomethacin. Because normal PRP can generate endoperoxides which act as substrates for $\mathrm{PGI}_{2}$ formation in the endothelial cells, indomethacin treatment of the monolayers would not be expected to inhibit $\mathrm{PGI}_{2}$ generation in the presence of normal PRP. Fibroblast production of $\mathrm{PGI}_{2}$ was similarly inhibited by indomethacin, tranylcypromine, and 15-HPAA (data not shown).

Inactivation of $\mathrm{PGI}_{2}$ in endothelial cell monolayer supernates. The $\mathrm{PGI}_{2}$ activity of supernatant fluid removed from endothelial cell (or fibroblast) monolayers stimulated with all of the agents tested was destroyed by brief boiling or acidification to $\mathrm{pH} 3$ for $10 \mathrm{~min}$. Inhibitory activity was also lost when the supernate was incubated at room temperature for $30 \mathrm{~min}$ at $\mathrm{pH}$ 7.4 , or at $37^{\circ} \mathrm{C}$ for $15 \mathrm{~min}$. Activity was preserved for several hours when the supernate was kept on ice at $\mathrm{pH}$ 7.4 or $\mathrm{pH} 8.6$, and for days when it was frozen at $-70^{\circ} \mathrm{C}$ at $\mathrm{pH} 8.6$.

Effects on $\mathrm{PGI}_{2}$ production of incubating endothelial cell monolayers with trypsin and chymotrypsin. Endothelial cell monolayers were incubated for $2 \mathrm{~min}$ with $0.0001-0.0025 \%$ trypsin and the culture supernatant fluid then examined for $\mathrm{PGI}_{2}$ activity. These concentrations of trypsin had no effect on platelet aggregation or on thrombin-induced $\left[{ }^{14} \mathrm{C}\right]$ serotonin release from platelets. The cells appeared to contract during trypsin treatment when viewed by phase microscopy, but did not detach from the culture flask. The trypsintreated monolayers released $\mathrm{PGI}_{2}$ and significantly shifted the $\mathrm{T}_{50}$. Thus, monolayers treated with $0.001 \%$ trypsin gave a $\Delta \mathrm{T}_{50}=225 \pm 32$ (mean \pm S.E.M., $P$ $<0.01$ ). Prior treatment of trypsin with a twofold excess of soybean trypsin inhibitor abolished the stimulatory effect of trypsin on $\mathrm{PGI}_{2}$ production. The trypsin concentration required for this effect on the $T_{50}$ was, on a molar basis, about 200 -fold greater than the thrombin concentration which gave a similar effect. Chymotrypsin at a concentration of $0.001 \%$ did not stimulate $\mathrm{PGI}_{2}$ activity.

Fibroblasts incubated with similar concentrations of trypsin did not produce $\mathrm{PGI}_{2}$.

\section{DISCUSSION}

Monolayers of cultured human endothelial cells produced $\mathbf{P G I}_{2}$ after brief incubation with sodium arachi- donate, thrombin, the calcium ionophore A 23187, and trypsin, or after mechanical stimulation. However, resting monolayers, or monolayers incubated with ADP, or epinephrine did not produce $\mathrm{PGI}_{2} \cdot \mathrm{PGI}_{2}$ activity was assayed by inhibition both of platelet aggregation and of $\left[{ }^{14} \mathrm{C}\right]$ serotonin release. Fibroblasts produced $\mathrm{PGI}_{2}$ only after incubation with arachidonate. Our results with fibroblast monolayers are consistent with the findings of Baenziger et al, who showed that $\mathrm{PGI}_{2}$ is produced by fibroblasts stimulated by scraping the cells from the culture dish (13) and by intact cells incubated with arachidonate. ${ }^{2}$ Confirmation that the inhibitor produced by the monolayers was a prostaglandin was obtained by blocking its production with indomethacin or aspirin. ${ }^{3}$ Such indomethacin-treated monolayers, however, could generate $\mathrm{PGI}_{2}$ activity when they were placed in contact with normal, heparinized PRP which acted as a source of prostaglandin endoperoxides. Specific evidence that the platelet-inhibitory activity was $\mathrm{PGI}_{2}$ was provided by studies in which 15-HPAA and tranylcypromine, inhibitors of endoperoxide conversion of $\mathrm{PGI}_{2}$, prevented its synthesis $(15,16)$. Moreover, heating or acidifying the active cell supernates, conditions known to inactivate $\mathrm{PGI}_{2}$ but not prostaglandin $\mathrm{D}_{2}$ (15), abolished the inhibitory activity. These experiments clearly indicated that the inhibition of platelet aggregation and of thrombin-induced $\left[{ }^{14} \mathrm{C}\right]$ serotonin release from platelets exposed to the cell monolayer supernates was a result of $\mathrm{PGI}_{2}$ in the supernates.

Because thrombin stimulated the production of $\mathrm{PGI}_{2}$ by the endothelial cell monolayers without addition of arachidonate, the substrate for $\mathrm{PGI}_{2}$ synthesis must have been endogenous arachidonate. We suggest that thrombin bound to a recently described specific receptor (18) on the endothelial cells and then activated phospholipase $A_{2}$, which in turn released arachidonic acid from membrane phospholipid for prostaglandin synthesis. DFP-treated thrombin did not stimulate endothelial cell $\mathrm{PGI}_{2}$ production, although DFP-treated thrombin has been reported to bind endothelial cells as well as native thrombin (18). This suggests that thrombin protease activity is required for the stimulation of $\mathrm{PGI}_{2}$ synthesis in endothelial cell monolayers. Endothelial cell monolayers restimulated with thrombin produced little or no $\mathrm{PGI}_{2}$. The poor response to thrombin stimulation after an initial arachidonate stimulus probably represents depletion of endogenous arachidonate recruited during the initial response. The lack of response to the second of two sequential thrombin stimuli may represent depletion of endogenous arachidonate and(or) destruction of a thrombin-sensitive cellular component.

Monolayers of stimulated endothelial cells produced

\footnotetext{
${ }^{2}$ Baenziger, N. Personal communication.

${ }^{3}$ Jaffe, E. A., C. W. Ley, and B. B. Weksler. Manuscript in preparation.
} 
$\mathrm{PGI}_{2}$ in a "burst"-like pattern. $\mathrm{PGI}_{2}$ peaked 2-3 min after stimulation and could no longer be detected at 10 min. The limiting factor appeared to be the availability of arachidonate. Thus the cells again produced $\mathrm{PGI}_{2}$ when exogenous arachidonate was added. It is possible that in intact blood vessels in vivo, exogenous arachidonate from plasma may continuously replenish the endothelial cells' endogenous arachidonate pool and thus allow the endothelial cells to respond continuously with $\mathrm{PGI}_{2}$ production to a variety of stimuli, either chemical or mechanical. Because mechanical stimulation of endothelial cell monolayers produced $\mathrm{PGI}_{2}$, mechanical stimuli in vivo (i.e., shearing forces resulting from blood flow) may also stimulate $\mathrm{PGI}_{2}$ production.

The ability of trypsin to stimulate $\mathrm{PGI}_{2}$ production indicates that other enzymes besides thrombin may be capable of stimulating $\mathrm{PGI}_{2}$ synthesis by endothelial cells. It is likely that proteolytic enzymes activate endothelial cell phospholipase $A_{2}$ from a precursor form (19). Because $\mathrm{PGI}_{2}$ produced by endothelial cells has been shown to inhibit polymorphonuclear leukocyte function (20), the ability of various proteolytic enzymes to induce $\mathrm{PGI}_{2}$ synthesis may represent a modulating mechanism in the control of inflammatory processes.

The ionophore A 23187 has recently been shown to stimulate prostaglandin and thromboxane synthesis in platelets by mobilizing intracellular calcium and by activating phospholipase $A_{2}$, a calcium-dependent enzyme $(21,22)$. At similar concentrations $(5-10 \mu \mathrm{M})$ to those giving maximal thromboxane $\mathrm{A}_{2}$ production in platelets (21), ionophore A 23187 stimulated $\mathrm{PGI}_{2}$ production in endothelial cell monolayers in the absence of exogenous arachidonate, which suggests that the mobilization of intracellular calcium can also activate phospholipase $A_{2}$ in endothelial cells, thus making endogenous arachidonate available for $\mathrm{PGI}_{2}$ synthesis. The finding that indomethacin treatment of the cells blocked $\mathrm{PGI}_{2}$ synthesis induced by ionophore A 23187 is consistent with this mechanism, because indomethacin-treated endothelial cells cannot utilize arachidonate for $\mathrm{PGI}_{2}$ synthesis.

Other agents which stimulate platelets, namely ADP and epinephrine, did not stimulate endothelial cell monolayers to synthesize $\mathrm{PGI}_{2}$. Assessment of ADPmediated stimulation of $\mathrm{PGI}_{2}$ production may be complicated by the fact that endothelial cells possess ADPase activity $(23,24)$. Thus, ADP added to the endothelial cells would be degraded. It is possible that endothelial cells can respond to locally higher doses of ADP, but these interfere with our assay method. Epinephrine did not stimulate $\mathrm{PGI}_{2}$ production. In fact, epinephrine sensitized the aspirin-treated platelets and decreased the $\mathrm{T}_{50}$.

In conclusion, intact monolayers of cultured human endothelial cells can synthesize $\mathrm{PGI}_{2}$ either from endogenous arachidonic acid when the cells are stimulated by thrombin, trypsin, or the ionophore $\mathrm{A} 23187$, or from exogenous endoperoxides. Production of thrombin at a site of vascular injury could, by stimulating $\mathrm{PGI}_{2}$ production by endothelial cells adjacent to the injured area, limit the number of platelets involved in the primary hemostatic response and help to localize thrombus formation.

\section{ACKNOWLEDGMENTS}

We thank Christine Baranowski and Joyce Knapp for excellent technical assistance and Naomi Nemtzow for typing the manuscript.

This work was supported by The National Institutes of Health through Specialized Center for Thrombosis grant HL 18828, the New York Heart Association, and the Arnold R. Krakower Hematology Foundation.

\section{REFERENCES}

1. Moncada, S., R. Gryglewski, S. Bunting, and J. R. Vane. 1976. An enzyme isolated from arteries transforms prostaglandin endoperoxides to an unstable substance that inhibits platelet aggregation. Nature (Lond.). 263: 663665.

2. Johnson, R. A., D. R. Morton, J. H. Kinner, R. R. Gorman, J. C. McGuire, F. F. Sun, N. Whittaker, S. Bunting, J. Salmon, S. Moncada, and J. R. Vane. 1976. The chemical structure of prostaglandin X (prostacyclin). Prostaglandins. 12: 915-927.

3. Moncada, S., E. A. Higgs, and J. R. Vane. 1977. Human arterial and venous tissues generate prostacyclin (prostaglandin $\mathrm{X})$, a potent inhibitor of platelet aggregation. Lancet. I: 18-20.

4. Dusting, G. J., S. Moncada, and J. R. Vane. 1977. Prostacyclin (PGX) is the endogenous metabolite responsible for relaxation of coronary arteries induced by arachidonic acid. Prostaglandins. 13: 3-15.

5. Raz, A., P. C. Isakson, M. S. Minkes, and P. Needleman. 1977. Characterization of a novel metabolic pathway of arachidonate in coronary arteries which generates a potent endogenous coronary vasodilator. J. Biol. Chem. 252: 1123-1126.

6. Gorman, R. R., S. Bunting, and O. V. Miller. 1977. Modulation of human platelet adenylate cyclase by prostacyclin (PGX). Prostaglandins. 13: 337-338.

7. Tateson, J. E., S. Moncada, and J. R. Vane. 1977. Effects of prostacyclin (PGX) on cyclic AMP concentrations in human platelets. Prostaglandins. 13: 389-397.

8. Lapetina, E. G., C. J. Schmitges, K. Chandrabose, and P. Cuatrecasas. 1977. Cyclic adenosine 3'5'-monophosphate and prostacyclin inhibit membrane phospholipase activity in platelets. Biochem Biophys. Res. Commun. 76: 828-835.

9. Gerrard, J. M., J. D. Peller, T. P. Krick, and J. G. White. 1977. Cyclic AMP and platelet prostaglandin synthesis. Prostaglandins. 14: 39-50.

10. Weksler, B. B., A. J. Marcus, and E. A. Jaffe. 1977. Synthesis of prostaglandin $\mathrm{I}_{2}$ (prostacyclin) by cultured human and bovine endothelial cells. Proc. Natl. Acad. Sci. U. S. A. 74: 3922-3926.

11. Jaffe, E. A., R. L. Nachman, C. G. Becker, and C. R. Minick. 1973. Culture of human endothelial cells derived from umbilical veins. J. Clin. Invest. 52: 2745-2756.

12. Mustard, J. F., D. W. Perry, N. G. Ardlie, and M. A. Packham. 1972. Preparation of suspensions of washed platelets from humans. Br. J. Haematol. 22: 193-204.

13. Baenziger, N. L., M. J. Dillender, and P. W. Majerus. 1977. Cultured human skin fibroblasts and arterial cells 
produce a labile platelet-inhibitory prostaglandin. Biochem. Biophys. Res. Commun. 78: 294-301.

14. Rodbard, D., and G. R. Frazier. 1975. Statistical analysis of radioligand assay data. Methods Enzymol. 37: 3-22.

15. Moncada, S., P. Needleman, S. Bunting, and J. R. Vane. 1976. Prostaglandin endoperoxide and thromboxane generating systems and their selective inhibition. Prostaglandins. 12: 323-333.

16. Moncada, S., R. J. Gryglewski, S. Bunting, and J. R. Vane. 1976. A lipid peroxide inhibits the enzyme in blood vessel microsomes that generates from prostaglandin endoperoxides the substance (prostaglandin X) which prevents platelet aggregation. Prostaglandins. 12: 715738.

17. Stanford, N., G. J. Roth, T. Y. Shen, and P. W. Majerus. 1977. Lack of covalent modification of prostaglandin synthetase (cyclo-oxygenase) by indomethacin. Prostaglandins. 13: 669-675.

18. Awbrey, B. J., W. G. Owen, J. C. Hoak, and G. L. Fry. 1977. Binding of thrombin to endothelial cells. Blood. 50(Suppl. 1): 257. (Abstr.)

19. Pickett, W. C., R. L. Jesse, and P. Cohen. 1976. Trypsin- induced phospholipase activity in human platelets. Biochem. J. 160: 405-408.

20. Weksler, B. B., J. M. Knapp, and E. A. Jaffe. 1977. Prostacyclin $\left(\mathrm{PGI}_{2}\right.$ ) synthesized by cultured endothelial cells modulates polymorphonuclear leukocyte function. Blood. 50(Suppl. 1): 287. (Abstr.)

21. Knapp, H. R., O. Oelz, L. J. Roberts, B. J. Sweetman, J. O. Oates, and P. W. Reed. 1977. Ionophores stimulate prostaglandin and thromboxane biosynthesis. Proc. Natl. Acad. Sci. U. S. A. 74: 4251-4255.

22. Pickett, W. C., R. L. Jesse, and P. Cohen. 1977. Initiation of phospholipase $A_{2}$ activity in human platelets by the calcium ion ionophore A 23187. Biochim. Biophys. Acta. 486: 209-213.

23. Heyns, A du P., C. J. Badenhorst, and F. P. Retief. 1977. ADPase activity of normal and atherosclerotic human aorta intima. Thromb. Haemostasis. 37: 429-435.

24. Glasgow, J. E., and F. A. Pitlick. 1977. Type-specific differences in the ability of cultured human cells to hydrolyze adenine nucleotides and to trigger the platelet release reaction. Fed. Proc. 36: 1082. (Abstr.) 